\title{
SILENCES AND SECRETS OF FAMILY, COMMUNITY AND THE STATE
}

\author{
FRANCES PINE
}

GOLDSMITHS, UNIVERSITY OF LONDON

\author{
HALDIS HAUKANES
}

UNIVERSITY OF BERGEN

\begin{abstract}
In this article, we suggest that silence is often more about remembering than forgetting. We consider ways in which silences can occupy and dominate state discourse, community knowledge, family stories and individual narratives. Drawing on research material from Poland and the Czech Republic in the late socialist and post-socialist periods, we look at ways similar patterns of narrative fusion take place in various contexts in which both the public and the private domains are often shadowed by things veiled in secrecy and hidden from the general gaze. We argue that personal family and kin accounts of private things which for some reason cannot be spoken become entangled with, and to some extent communicated through, broader and more public historical narratives, and vice versa, and show how partial accounts are thus transmitted from generation to generation even while remaining largely unspoken.

In developing our argument, we focus on the idea of walls of silence and on the process of drawing boundaries between people and the state, between generations (grandparents, parents and children) and between insiders and outsiders of communities. Suggesting that silence may be loud or quiet, we look at registers of silence and the ways in which they operate at the different levels of state, community and household. We ask what it means to hold certain kinds of knowledge, or to be excluded from these. At times, and for some people, knowledge may be a source of power or social or economic capital; for others, or in other contexts, being excluded from or rejecting knowledge, and thus not being privy to the subtexts of silence, may be a source or freedom and potential or possibility.
\end{abstract}

KEYWORDS: Walls of silence, registers of silence, gender, generation, household, socialism, post-socialism, memory and commemoration, history, the state 
INTRODUCTION: THINKING ABOUT SILENCE

"There is no speech proper without this background of silence;... all speech answers to the sound of silence” (Slavoj Žižek, in Kenny 20II, 68-69).

\section{Secrets and Silences Under and After Socialism}

There is a certain ambiguity to the idea of silence. It may be associated positively with peace, and a calm stillness; but conversely it is often linked negatively to restriction, repression and coercion. In the latter case, it is represented as something which, like a layer of ice or glass, has to be broken or shattered. This ambiguity of the term is a reflection of its power.

The power of silence caught the imagination of feminist writers in the 1970s and 1980s. In On Lies, Secrets, Silence Adrienne Rich wrote: "Lying is done with words, and also with silence." (Rich 1979) Her book centred on trust and honesty, exploring the emotional dimensions of lies and secrets. Tilly Olsen, in Silences (1978), discussed similar issues in relation to the voices that should have been there but were hauntingly absent: women's voices, black voices and voices of people of colour and excluded ethnicities. For both of these writers, silences were political, and were affective, emotional. They showed that silences generated at the level of the individual and maintained within close personal relationships were simultaneously perpetuated by popular culture and by state policies and ideologies. Silences punctuated personal, popular and state discourses. They spoke to an absence that should have been present.

In oral history and ethnography we can find a similar relationship between what is uttered and what is not, between the story told and the omissions that mark it. As in the work of Rich and Olsen, what is often striking is the political sound of silences, related to power, authority and regimes of truth and memory, and the relation between these "big" silences and the silences of everyday/ordinary life.

Over the past few years, a number of radical attempts to reject mainstream history and to provide space for different, often very divergent, stories have taken place. In North America, Europe and Africa, monuments have been toppled or denounced and the long-acclaimed heroes that they represent - military and political figures, and members of current and former social and economic elites - have been discredited, and their connections to slavery, racism and colonialism publicly revealed. One of the main aims of these acts has been to break public silences, and to reveal concealed truths and alternative histories.

Strikingly similar scenes took place three decades earlier, in 1989 and the early I990s, in an extraordinarily public breaking of collective silences and exposure of collective secrets. Statues of Stalin, Lenin and other communist heroes in cities, towns and villages throughout Eastern and Central Europe were defaced by angry crowds, pulled down and relegated to the dustbin of history or moved to themed statue parks. With changes in political systems or regimes, heroes were transformed into villains and 
criminals, and former villains resurrected as the "real" heroes (see Witeska-Mlynarczyk 20I4). In the wake of such enormous shifts in the tides of history, entrenched silences, which ordinary members of the public and the apparatus of state institutions had colluded to maintain, dissolved into confession and accusation. People came forward to tell their hidden stories or to throw light on hidden pasts, as old silences were broken and new ones emerged and grew. Processes of lustration - a form of public reckoning - were put into place, but were often highly contentious and politicized. As silences around the crimes and misdemeanours of 'the state' (in the persons of officials, police, politicians) on the one hand and of ordinary people living in "the state" on the other were broken, questions were raised about who was culpable. ${ }^{1}$ Throughout the whole socialist bloc, everyone knew that members of their families and their closest friends and neighbours might be informers, but they carried on with their daily lives. Silence shrouded truth at every level of society: there were the secrets that the state held both about and from people, and the secrets that people hid from the state (see Kotkin's account of surveillance during Stalinism, Kotkin 1995; for more recent accounts, see Alexievich 2013/2016). There was often a tension between loyalty to the state and loyalty to the family; but even more common was distrust and fear of the state, and trust (albeit slightly edgy) in family and personal networks of friendship, neighbourhood and work.

Perhaps because of the critical way the state socialist regimes have been portrayed in western political discourse, as well as internally by dissidents and more recently by politicians, academics and generally in popular culture of post-socialist societies, these silences, associated with oppression, corruption and opposition, have been dominant themes explored by historians and political scientists of the region. But, in ethnographic accounts and popular culture, other realms of silence are also revealed: silences within communities, families and households, silences between genders and generations, and silences held closely inside individual people. Many of these are small silences, halfknown or half-guessed at truths, stories carried by the members of one generation, or one house, but kept from another. Of course, there are other far heavier, sometimes terrible, silences which permeate this local level, as we see for instance in Jan Gross's account of the pogrom in the Polish town of Jedwabne in 194I (Gross 2003) that revealed a complicity of silence between the community and the state. The official line of the socialist government, that the violence and atrocities inflicted on Jews had been carried out by the occupying Germans, matched and reinforced the community account. In this case, the local narrative, masking a terrible act under the guise of war, and the socialist state narrative, which pushed a nationalist agenda, converged.

I We are aware that, throughout this essay, we are using concepts like the state, the nation and the community in ways that may appear to reify them, and to suggest that they have a clear and anthropomorphic existence in time and space. We want to stress that this is not how we understand these institutions and relationships. 
During socialism there were many political events and histories which, although they were not spoken of explicitly, were reflected upon obliquely (see for example Niethammar, 1992, Wanner 1998, Richardson 2004, Liber 202I). Ongoing critiques were kept alive in jokes which circulated widely, in rumours and stories recounted in kitchens over tea or vodka, and in films, plays and exhibitions that contained veiled references which everyone recognized. Since the fall of socialism there have been concerns about a kind of collective amnesia sweeping across the region, reflecting an apparent lack of engagement with the traumatic aspects of actually lived socialism (Ringel 2013, Trnka 2013). Politicians, local leaders and members of the general public call for a revival of historical memory. The fear of forgetting is connected to the ways that silence is managed, to the technologies of silence and memory. Walter Benjamin wrote about the obligation to remember, arguing that we must keep remembering, even when memory is most painful or seems long past and irrelevant, because to forget is to deny the lives of the dead and to allow a slide into a repetition of atrocious pasts. Benjamin described the angel of history, whose face is turned toward the past:

\footnotetext{
Where we perceive a chain of events, he sees one single catastrophe which keeps piling wreckage and hurls it in front of his feet. The angel would like to stay, awaken the dead, and make whole what has been smashed. But a storm is blowing in from Paradise; it has got caught in his wings with such a violence that the angel can no longer close them. The storm irresistibly propels him into the future to which his back is turned, while the pile of debris before him grows skyward. This storm is what we call progress. (Benjamin 1968, 257-258)
}

Benjamin captured the tension between the heavy anchor of the past and the compelling pull of the present/future. The storm of progress is a direct challenge to remembered pasts and histories; when the impetus to move forward overrules the inclination to remember the past, the resulting silence or forgetting seems more political than personal. But both personal and political contexts can generate boundaries between what is spoken and unspoken, and between those who hold and keep knowledge or memory and those for whom it is blocked or unknown.

\section{Silences of Different Weight}

Silence is often more about remembering than forgetting. Ethnographic accounts show that traumatic silence is a black hole which cannot be filled, an absence which permeates and disturbs family memory and disrupts transmission from generation to generation. Gendered spaces of silence often surround embodied events and memories: sex, pregnancy, miscarriage and abortion, domestic abuse and violence, illegitimacy and unequal status or class relations.

There are however different levels or registers of silence. Some silences are so loud that they constantly evoke memory or recognition. These are so laden with their unspoken content that it is impossible to escape their image or their weight. Silences 
such as those which for years surrounded the Holocaust both within and beyond Jewish communities, or those which veiled sexual abuse and violence within families or institutions, carry that weight of loudness; although things are unspoken, they are inscribed indelibly into people's lives and consciousness (Boyarin 1994, Antze and Lambek 1996, Hirsch 1999, Young 2000, Gross 2003). Other silences may be quieter. Such silences are not pressing but still uncomfortably present: things that are not mentioned or brought to the fore, because they are embarrassing, shameful or painful, or because they are illegal or ambiguous and better left below the public radar. And finally there are uneventful silences that carry little or no weight.

In this article we look at how different kinds of silence work together, at when and how they mirror or echo each other, and under what circumstances they may be broken. We focus on the idea of walls of silence. By this we mean the boundaries erected around and enclosing certain events or pasts experienced by individuals or families, within communities, or more widely within a region or nation. We consider the ways that the state imposes walls of silence, and how these resemble and differ from those erected within families and households. All silences are not of the same intensity or weight, and we want to distinguish between loud (sometimes deafening) and quiet (less marked) silences. Focusing on different registers of silence allows the consideration of what it means to hold certain kinds of knowledge, or to be excluded from these. Big events often bring different memory regimes together. They tend to take over and reform and reformulate history, but in so doing they may partly or temporarily silence other stories, memories or ways of seeing. At some times, and in some contexts, knowledge may be a source of power or social or economic capital; alternatively, being excluded from or rejecting knowledge, and not being privy to silenced subtexts, may be a source of freedom or possibility.

The ethnographic accounts we present are drawn primarily from our own research, beginning in Poland in the late 1970s (Pine) and in the Czech Republic in the early I990s (Haukanes), and continuing into the first decades of the 2Ist century. ${ }^{2}$ Researchers encounter different aspects of silence: there are the silences of people with whom we are working; silences produced by our methodologies (see Lamphere 2019); and silences in our own ethnographic accounts, prompted by ethical and personal decisions about what should and should not be published, by our sense of what is ours to tell and what is not. The latter has influenced the selection of material we present, as well as the mode of presentation and the presence or absence of particular details.

2 Haukanes started her ethnographic research in Czechoslovakia right after communism fell, and followed the post-communist transformation process in rural areas of the country throughout the I990s. In later years, she has done work in the Czech Republic among young people, exploring their imaginations of the future.

Pine began research in Poland in 1977, and has worked in southern, central and eastern Poland at different times, looking at kinship and gender, generation and households. 
The ethnographic cases from Czechoslovakia/the Czech Republic and Poland we are considering here are quite different. We want to explore certain themes and concepts through our discussion, but to make absolutely clear that the discussion is not straightforwardly comparative; we are not comparing like for like. The article is intended more as a thought piece, in which we try to consider different aspects of what silence is and means.

\section{CONTEXTS AND SPACES OF SILENCE}

\section{State Generated Silences: Dialectics of Subversion and Compliance}

Throughout the socialist bloc the state guarded its own silences, while simultaneously trying to break down the secrets of families and communities, erasing certain histories and people and promoting other histories which effectively silenced the alternative versions. Neighbours, friends and family members were encouraged to report on each other, breaking shared silences and revealing shared secrets. One of the most poignant and painful examples of this was the practice of rewarding school children if they informed on their parents. In I950s Poland, village children were given sweets and praised if they told their teachers what their parents discussed at home. So silence was invoked, and broken, in an ongoing battle between state and family, most famously represented in the tragic case of Pavlik Morozov, who became a Soviet child hero for reporting on his father. Loyalties were torn apart. The state was in essence claiming for itself the status of the true family, and in so doing attempting to engineer the rejection of the kin-based family. In communist ideology, the family was a bourgeois concept, underpinning the corruption at the heart of class structure, and something which would be replaced by the communist state: the state was to become the family (Khlinovskayá Rockhill 20IO). So Pavlik, breaking silence and revealing the small secrets of his family, came to represent symbolically the affective triumph of the state. Not surprisingly, silences encircling and protecting the family against the state became deeper and more entrenched.

The historical metanarratives of the communist regimes were carefully constructed to make empirical realities fit the law-bound march towards communism (Verdery 1996), enforcing a rather one-dimensional version of public "truth". Through this, huge "no-go" areas of public memory were generated, creating a split between public and private remembering (see Passerini 1992; Watson 1994). The following case demonstrates both the state's attempts to impose walls of silence, and the cracks that these walls inevitably contained.

In the I990s Haukanes examined local history books, called chronicles, written by lay people in a few villages in South Bohemia and South Moravia. ${ }^{3}$ She explored the

3 Haukanes has presented this case in detail elsewhere, and here we offer a shorter rendition of the original account (Haukanes I999, 2004 a and 2004b). 
relationship between state narratives (including state regulation of and prescriptions for chroniclers) and the narratives produced by these lay historians. The relationship of the Czech chroniclers to the big and small events they witnessed was complicated by competing claims to their voices. Haukanes found a clear demonstration of the eagerness and effort expended by the regime to insert its version of events into the chronicles and achieve control over what was told. In the 1950s, the means employed were indirect. Through guidebooks and directives a framework was laid for the rendering and interpretation of local events, but no measures were taken to stop personal and/or subversive utterances. When in the I950s one chronicler wrote critically about the collectivisation process, no attempt was made to silence him or change what he had written. However, in the years following 1968 control became more intrusive and direct. The same chronicler who had expressed his discontent over collectivisation, now wrote with enthusiasm about the Prague Spring, before moving on to describe his and other villagers' disappointment about the August invasion and to report that people had now started to hate the Soviet Union. This time, however, his utterances were not accepted: he was forced to correct his own writings in the chronicle and overlay his original account with a version which followed the state sanctioned line. His voice of opposition was silenced, although his initial rendering of events, and the corrections which had been written over them, remained in the chronicle for everyone to see - one clear crack in the wall of silence.

Although he did continue as a chronicler, his yearly accounts became short, factual and apolitical. He continued to write more detailed accounts of village history though, in the form of a "private" village history book, a book which was not for public display and which thus was not subject to state control. In this book, beautifully decorated with maps, drawings and calligraphic letters, he did not include his former protests and critical comments. On the contrary, he employed both the periodisation and the vocabulary of the communist regime when describing the course of events. By the late I970s, it thus seems that the state's desired domination and control had been obtained, and alternative narratives of events had been muted. A loud silence, stretching even into the chronicler's private local history writing, had been imposed.

However, the chronicler's "non-regulated" accounts of "controversial" events, such as the collectivisation of agriculture in the I950s and the end of the Prague Spring in 1968, were not totally erased; rather, they were relocated to family spaces and oral accounts. According to his son, whom Haukanes interviewed, the chronicler spoke about what happened after 1968 to his children, and told them of the humiliation he suffered from having to correct his own rendering of events.

This case is a good example of ways in which the state attempted to enforce the telling of some narratives, inscribing them as history, while silencing others. But as we can see, cracks in the wall of silence are visible, both those displayed publicly through the corrections in the official chronicle, and those privately voiced. 


\section{Silences of Communities: Hiding From the State}

During the last decade of socialism, Pine observed many instances in the Polish Podhale where the house became a site of opposition to state control, particularly over economic activity, but simultaneously itself acted like the state in relation to the regulation of house members. ${ }^{4}$ The public face which the house presented to the state usually reflected a mixed economy, with some house members working in the state sector, in the service sector or in factories, shops and so forth, and some working wholly in agriculture and delivering milk, meat and grain to distribution cooperatives, and some working in both. However, nearly all houses had at least some members who were also involved in the grey or informal economy: providing services privately to tourists, selling foodstuffs and crafts privately in the local market or further afield and producing a range of goods for sale, some of which, such as sheepskin coats, were extremely expensive. Some of the more successful market women travelled all over the country and sometimes across borders to Czechoslovakia, Hungary and even Turkey, selling their wares and bringing back scarce goods much in demand in local markets. Finally, nearly every house in the village had at least one member who had travelled to Chicago on a tourist visa and had overstayed often by 3 or 4 years, working illegally and sending remittances home. All of these activities were hidden from the state, untaxed and performed in secret, at least from the eyes and ears of the outside. They were of course well known within the village and in the area (see Pine, 1993, 1999, 2014).

Older villagers told Pine stories about the past, which revealed a similarly ambivalent attitude to the state and ways in which villagers held secret knowledge close to them under a veil of silence. Stories of violence towards German or Soviet soldiers during or immediately after the war, and of political manoeuvring by clever villagers of German officials and Polish partisans during the war, were known inside villages, but hidden from the outside (see Pine 2002, 2007). Such narratives formed part of the narration of house, village and local identity, which pitted Górale against agents of the state in all of its guises: poor, uneducated Górale took on the power of greater forces and sometimes won, through various combinations of cleverness, trickery and violence (Pine 1999, 2002).

The important point about these examples is that they reflect the selective nature of silence. In the case of the Czech chronicles, the state attempted to silence the rendering of certain events, even though they were known by local people and shared within families. In the Polish case, conversely, local people themselves set up a boundary, or wall of silence, between inside and outside.

4 House here is used in the sense of a named group of people, primarily but not exclusively kin, who lived in one or more houses of the same housename, and who worked together on the same fields and were part of a joint economy; see Pine 1996. 


\section{Secrets of Houses, Families, and Generations}

Looking within households and families adds yet another dimension to our consideration of silence. Within the house, different generations may withhold information or parts of their lives from others. Men who have fought in wars or women who have been subjected to sexual violence may not pass on stories of those life events to their children, and perhaps not even to their spouses or parents. A migrant worker may send home remittances, stories and photographs all suggesting a successful life abroad, while in fact they may be unhappy and lonely, living on the edge of poverty in order to send their meagre earnings home. When they return home, they may maintain silence about their sufferings and continue to be seen as having completed a successful migration. A woman and her children may hide the extent of her husband's violence and alcoholism from the rest of the household, or the whole house membership may maintain a silence around sexual transgressions (premarital pregnancy, adultery, abuse), a public denial in relation to neighbours and the rest of the village. During the late socialist period, and in the very unsettled decade which followed socialism's demise, Pine observed and was told of many such silences in mountain villages.

Thus, secrets of the house were often in fact guessed, speculated upon or known by neighbours, and sometimes undoubtedly embellished in their re-telling. In such cases, silence was at the very least incomplete. It tended to be attached to interactions with, or transgressions of, ideologies of family, gender, church and state. Ultimately, these registers of family and state silences, and the ways in which they interweave with memory and forgetting, come together and address each other, implicitly or explicitly, time and time again (Pine 1999, 2007).

The story of Zofia, a Podhale woman very powerful in her village during the war and the early socialist years, illustrates these points. Zofia's son gave an account of his mother in the late I970s. He was in his 5os at the time and had been talking rather emotionally about his family. Then he suddenly said that his mother was a whore. Zofia had been dead for some years, but was still talked about often: she was, people said, very beautiful, she was a witch, she had the evil eye, she was a very shrewd business woman, she collaborated with the Germans and the partisans at the same time and fooled both, and so forth. In the regional archives, Pine came across a Góralenvolkkart in her name. This identity card was issued by the Germans to certain Górale deemed to be true Aryans, and could be taken to give some credence to the allegations of collaboration. But the bitterness Zofia's son expressed was not about this. Zofia had been intimate with the house's domestic servant, had a child with him, and physically bullied her husband. For her son, political trickery or collaboration, transgression at the level of state or nation, was less significant than the transgression of the rules of the house, social status and gender. This was a "known" silence of the house and the village, something that was spoken of, but rarely as specifically as her son had spoken about it to Pine on that occasion. Conversely, although the rumours of Zofia's dealings with 
the Germans were still brought up in passing, years after her death, this was mainly with a sense of admiration at her cleverness. The existence of the Goralenvolk card was unlikely to have been known in the village, and certainly not widely. It was more of a state, or outside, silence than a silence of the house.

\section{Escaping the Past by Closing off Sound?}

Zofia's story shows that silence can be a lack of telling; but it also may reflect a failure to transmit knowledge, or a part of the story that is left out in one context, but may appear, possibly in a different guise, in another. Within houses and families we see both the weight of traumatic silences and the lightness of silences which represent something forgotten because it is no longer told, or is told but not heard. Below is an account of such a lack of transmission, in both an affective and a material sense, between generations.

In rural South Bohemia, Haukanes became acquainted with a woman who had been married during the 1940 s to a large landowner. The family lost all their land to the cooperative in 1957, and experienced many hardships thereafter: "I have lived here for 50 years, but 33 of them weren't very happy," she said. "You cannot even imagine what I have lived through.... My husband didn't want to join the JZD [the cooperative farm], so they put him in prison.... Velvet revolution, puh, it shouldn't have been velvet; they should have been properly punished, all of them" (see Haukanes I999, 2004a).

Františka seemed to remember everything that happened to the family in great detail. She referred to conversations that had taken place in the 1950s and 6os, and quoted directly what was said to her and her husband. In public, she appeared to be reticent. To her family (and to Haukanes), however, she spoke endlessly about the injustices committed against her both by fellow communist villagers and higher officials. She was strongly attached to the land they once owned, and would have liked to take it back through restitution from the agricultural cooperative and to farm it again with her family.

Františka was very bitter. But she had been unable to pass on her bitterness to the next generation. Her son did not want to listen to her stories, distancing himself from the troubles of the past. And to Františka's great disappointment, none of her children was interested in taking up farming. Františka tried to teach her two grandsons about their family land, hoping that one of them would be willing to make private farming a way of living. But in vain. After finishing school in the mid-I99os, the two grandsons trained as mechanics.

This case may be seen as an example of a rejection of the past, and perhaps as an attempt to erect a wall of silence in order to escape the weight of family obligations. Františka's grandsons were young in the turbulent years following 1989. In planning their futures, they turned their back on the family's past as landowners and farmers, closing a door in order to move forward. Haukanes found a similar (but not identical) lack of engagement with the past when she investigated the future plans and dreams of young people born in the 1990s (Haukanes 2013a, 2013b, 2017). The many topics discussed 
during interviews involved the young people's imaginations of the future of their society/country. During these vivid discussions, no references were made to communism, state socialism or the communist/socialist regime. No comparison was made with former times when they described their fears for the future, not even when dictatorship was mentioned, as it was on a couple of occasions. Haukanes asked them about their family histories, what their parents and grandparents do or did for a living and their roots in the region where they were living. Some of the young people had vague ideas about their ancestors' whereabouts, while others spoke in greater detail about their families, but references to communism/socialism were very rare and just made in passing.

In this case, we do not have direct access to the intergenerational transmission of experiences and knowledge, i.e. to what actually happened in the families, and can only speculate about what the young people's lack of interest in the past may signify. It may result from a wall of silence intentionally erected by parents and grandparents, for example to avoid exposing their own "non-heroic" pasts during communism. We are just as inclined to interpret it as a residual silence generated by the desire of younger generations for a different kind of future, a future where the socialist past of their country does not feel of relevance at all.

In the Podhale in the early 200os, Pine noted a similar move away from the past and towards a more open imagined future. In the last decade of socialism, a generational change was taking place within Podhale village families. Oral histories and life stories from older villagers, those who had become adults before or during the Second World War, paint a picture of a very poor village, quite isolated and excluded from wider Polish society. Those born during the Hapsburg Empire remembered the massive out migrations from Galicia to Chicago in the late $19^{\text {th }}$ and early $20^{\text {th }}$ centuries, the "transition" from Austro Hungary to Poland, Nazi occupation and the establishment of state socialism. They identified themselves in terms of their house, village, and region, and as Górale, not as Poles. Their children and grandchildren, born into socialism, had mostly attended school for at least 5 years. Unlike their parents, they were literate. They were still caught in poverty, and also experienced the Stalinist regime of fear, remembered primarily as pressure to report on their parents in exchange for sweets at school.

But the next generation of children, born in the 6os and 70s, had been educated in the state socialist school system. On the whole, this generation learned and internalised a version of being Polish that was different from being Górale. These children could switch easily between dialect and Polish, which meant that they could speak easily to teachers, officials and other outsiders - and also that they could move into dialect to mask their conversations from these people. A few dreamed of university or different lives, but most expected to stay in the village and continue farming. By the early 200os, however, many young people identified themselves first as Polish and as European, rather than as Górale. Some moved to the city to study at technical college or university, or worked abroad for some years, planning eventually to set up in business, 
possibly in the mountains, but equally possibly elsewhere. In effect, the walls of silence that had been erected by the Górale against outsiders for decades were being eroded by a new sense of being part of the outside, of a wider, even global, community. With these changes, new histories are being forged and old stores forgotten, while different absences and silences are also being formed.

\section{FINAL REFLECTIONS}

Silence is particularly complicated because it cross-cuts social contexts, spaces and relations of both intimacy and power. We have tried to show here that coerced silence and voluntary silence are different, but may co-exist, and that they can be heavy or light, conventionalised or subversive. Parallels exist between the power structures of different spaces and the ways that these interact with silence and secrets. Starting with the state and continuing on to the community, the house and the individual, we have argued that different regimes of silence have their own archaeology, of which each layer is potentially a site of struggle or counter-history: the silences that hide the state's own secrets, the silences that the state tries to impose and the silences others build to keep the state out that the state in turn tries to break or shatter. We have suggested that there are parallels to this pattern in other spaces, those of the community and the household/family. The community may try to impose silence on its members, in relation to the state or a wider public, it may use silence to cover its own secrets and it may, as a collective, try to reveal what lies behind the silences of its members. Families hold their own silences against other households and families, and powerful members within the family silence less powerful ones, while less powerful members also hold on to their own secrets. Members of the junior generations turn on senior kin to expose their secrets to the outside or, perhaps even more commonly, they refuse to listen to the stories the seniors want to pass on, as we have seen in several examples in this article. Although the registers of silence vary according to institution and structure, very often the silences themselves evoke events and relationships which may hold great significance at a collective or individual level, even without being spoken aloud.

What also emerges from this discussion is that silences are nearly always partial, in both senses of the word. They are imposed to serve, or are partial to, particular interests, and they are only partly (partially) effective. Nothing that we have discussed in this article has been totally silenced - much of what we speak about in discussing silence is relational, silenced in relation to some audiences and heard or known by others. To go back to our earlier references to feminist writings, what we are really talking about is an absence: something missing from an account, or from history or memory, which should have been present. But also, on another level, something which is remembered and recounted in some other context: to a later generation, at a kitchen table, with reference 
to a much bigger (or smaller) event, when a regime changes. The silences which are recognised and identified as such, which are in a sense the loudest, are also the most evocative, precisely because they speak to submerged or erased memories, or to times and events which are not spoken but are nonetheless, at some level at least, recalled.

\section{REFERENCES}

Alexievich, Svetlana. 2013/2016. Second-hand Time. London: Fitzcarraldo editions.

Antze, Paul and Michael Lambek, eds. 1996. Tense Past: Cultural Essays in Trauma and Memory. New York: Routledge.

Benjamin, Walter. 1968. (1955) Illuminations (Theses on the Philosophy of History, 253-264). New York: Schocken Books.

Boyarin, Jonathan, ed. 1994. Remapping Memory: the Politics of TimeSpace. Minneapolis: University of Minnesota Press.

Gross, Jan. 2003. Neighbours: the destruction of the Jewish Community in Jedwabne, Poland, I94I. London: Arrow Books.

Haukanes, Haldis. 1999. Grand Dramas - Ordinary Lives. State, Locality and Person in Post-Communist Czech Society. Thesis for the degree of Dr. polit, Department of Social Anthropology, University of Bergen, Norway.

Haukanes, Haldis. 2004a. Velké dramata, obyčejné životy. Postkomunistické zkušenosti na českém venkově. (Grand Dramas - Ordinary Lives. Post-communist Experiences in the Czech Countryside). Prague: Sociologické nakladatelství SLON.

Haukanes, Haldis. 2004b. "The Power of Genre. Local history-writing in Communist Czechoslovakia." In Religion, Politics and Memory. The Past meets the Present in Contemporary Europe, edited by Frances Pine, Deema Kaneff and Haldis Haukanes, 93-I08. Berlin: Lit Verlag.

Haukanes, Haldis. 2013a. "Precarious Lives: Narratives of Hope, Loss and 'Normality' among Different Generations of Czechs". Focaal. Journal of Global and Historical Anthropology 66: 47-57.

Haukanes, Haldis. 20I3b. "Belonging, Mobility and the Future: Representations of Space in the Life Narratives of Young Rural Czechs”. Young. Nordic Journal of Youth Research 2I (2); 193-210.

Haukanes, Haldis. 2017. "Futures Full of Promise, Futures of Despair. Contrasting Temporalities in the Life Narratives of Young Czechs." Slovak Ethnology 65 (2): I2O-I33.

Hirsch, Marianne. 1999. "Projected Memory: Holocaust Photography in Personal and Public Fantasy." In Acts of Memory: Cultural Recall in the Present, edited by M. Bal, J. Crewe, and L. Spitzer, 3-24. Hanover: University Press of New England.

Kenny, Colum. 20Ir. The Power of Silence: Silent Communication in Daily Life. London: Routledge.

Kotkin, Stephen 1995. Magnetic Mountain: Stalinism as a Civilization. Berkeley and Los Angeles, London: University of California Press.

Lamphere, Louise. 2020. "Omissions and Silences in my Navajo Fieldwork: From Kinship Studies to Gendered Life Histories.” Journal of Anthropological Research 78 (I): 59-73.

Liber, Elena. 202I. "And That's How it Was": Small Stories of Big Histories in Post-Soviet Ukraine. Unpublished PhD Thesis. Goldsmiths, University of London.

Niethammar, Lutz. 1992. "Where Were You on I7 June. A Niche in Memory." In Memory and Totalitarianism, edited by Luisa Passerini, 45-70, Oxford: Oxford University Press.

Olsen, Tilly. 1978. Silences. New York: Delacorte Press. 
Passerini, Luisa, ed. 1992. Memory and Totalitarianism. Oxford: Oxford University Press

Pine, Frances. 1996. "Naming the House and Naming the Land: Kinship and Social Groups in the Polish Highlands." Journal of the Royal Anthropological Institute 2: 443-459.

Pine, Frances. 1999. "Incorporation and Exclusion in the Podhale". In Lilies of the Field: Marginal People who Live for the Moment, edited by S. Day, E. Papataxiarchism and M. Stewart, 45-60. Boulder: Westview Press.

Pine, Frances. 2002. "The Cows and the Pigs are His, the Eggs are Mine: Women's Labour and Entrepreneurial Activities in Rural Poland”. In Socialism: Ideals, Ideologies and Local Practice, edited by C.M. Hann, 95-II3. London: Routledge.

Pine, Frances. 2002. "The City and the Country." In Postsocialist Peasants? Rural and Urban Constructions of Identity in Eastern Europe, East Asia and the Former Soviet Union, edited by Pamela Leonard and Deema Kaneff, I60-179. London: Palgrave.

Pine, Frances. 2007. "Memories of Movement and the Stillness of Place: Kinship and Migration in the Polish mountains". In Ghosts of memory, edited by Janet Carsten, I04-125. Oxford: Blackwells.

Pine, Frances. 20I4. "Living in the Grey Zones: When Ambiguity and Uncertainty are the Ordinary." In Exploring the Grey Zones: Governance, Conflict and (In)Security in Eastern Europe, edited by Ida Harboe and Martin Frederiksen, 25-40. London: Anthem Press.

Rich, Adrienne. 1979. On Lies, Secrets, Silence: Selected prose 1966-1978. New York and London: Norton.

Richardson, Tanya. 2004. "Disciplining the Past in Post-Soviet Ukraine: Memory and History in Schools and Families." In Religion, Politics and Memory. The Past Meets the Present in Contemporary Europe, edited by Frances Pine, Deema Kaneff and Haldis Haukanes, I09-132. Berlin: Lit Verlag.

Ringel, Felix. 20I3. "Differences in Temporal Reasoning. Temporal Complexity and Generational Clashes in an East German City." Focaal 66: 25-25.

Rockhill, Elena Khlinovskayá. 2010. Lost to the State: Family Discontinuity, Social Orphanhood and Residential Care in the Russian Far East. New York/Oxford: Berghahn Books.

Trnka, Susanna. 20I3. "Forgotten Pasts and Fearful Futures in Czechs' Remembrances of Communism". Focaal 66: 35-46.

Verdery, Katherine. 1996. What was Socialism and What Comes Next? Princeton: Princeton University Press.

Wanner, Catherine. 1998. Burden of Dreams: History and Identity in Post Soviet Ukraine. Philadelphia: University of Pennsylvania Press.

Witeska-Młynarczyk, Anna. 20I4. Evoking Polish Memory: State, Self and the Communist Past in Transition. Warsaw: Warsaw Studies in Contemporary History.

Watson, Rubie S, ed. 1994. Memory, History and Oppression under State Socialism. Santa Fe: School of American Research Press.

Young, James E. 1994. The Texture of Memory. Holocaust Memorials and Meaning. New Haven and London: Yale University Press.

\section{AUTHORS' CONTACTS:}

Frances Pine

Department of Anthropology, Goldsmiths, University of London

E-mail: f.pine@gold.ac.uk

Haldis Haukanes

Department of Health Promotion and Development, University of Bergen, Norway

E-mail: haldis.haukanes@uib.no

ORCID: 0000-0002-996I-I535 